\title{
Cytogenetic Studies in North American Minnows (Cyprinidae) VII. Karyotypes of 13 species from the southern United States
}

\author{
J. R. Gold, W. D. Womac, F. H. Deal and J. A. Barlow, Jr. \\ Genetics Section, Texas A\&M University, College Station, Texas 77843, U.S.A.
}

Received April 19, 1979

Recent studies in several plant and animal groups have strongly emphasized the importance of chromosome structural change in evolution. Specifically, many rapidly evolved taxa appear to have undergone considerably more rapid and extensive chromosomal change than slowly evolved taxa (Wilson 1976, Prager and Wilson 1975, Wilson et al. 1975, Levin and Wilson 1976, Prager et al. 1976, Bush et al. 1977), and rates of speciation and organismal evolution (morphology, behavior, etc.) in certain groups are positively correlated with rates of chromosomal change. It is thought that chromosome structural rearrangements could facilitate both speciation and adaptive evolution at the organismal level by functioning as cytogenetic reproductive isolating mechanisms, by altering patterns of gene expression (regulation), or by creating adaptive super-genes which cannot easily be broken up by recombination (White 1973, 1977, 1978, Grant 1973, Wilson 1975, 1976, Bush et al. 1977).

In this paper we continue our survey of karyotypes of cyprinid fishes endemic to North America in the search for those genetic changes whose evolutionary rate and degree correspond with the rapid evolution exhibited by these fishes. Cyprinids in North America represent an essentially monophyletic group of more than 200 species (35-40 genera), all of which with one exception are placed in a single subfamily, the Leuciscinae (Miller 1959). The oldest leuciscine fossils in North America date to the Miocene (Miller 1965), but the majority are found in Pliocene and Pleistocene deposits (Miller 1965, Kimmel 1975, Smith 1975), suggesting that many species are of relatively recent origin. One genus, Notropis, contains over 100 living representatives (Miller 1965), most of which may have evolved only in the last 10 million years (Gold et al. 1979a). Herein, the karyotypes of 13 species belonging to 8 North American cyprinid genera are described. Chromosome data from all North American Cyprinidae assayed to date are summarized, and the pattern of gross karyotypic change in relation to evolution in these fishes is discussed.

\section{Materials and methods}

The 13 cyprinids examined in this study were collected by seining from the following localities in Texas and Louisiana: Notropis atrocaudalis and Semotilus atromaculatus (Mill Cr., San Augustine Co., Tx.); Dionda episcopa (San Marcos R., Hays Co., Tx.); Notropis amabilis (Blanco R., Hays Co., Tx.); Notropis atherinoides 
(Little Pine Bayou, Jefferson Co. and Hardin Co., Tx.); Notropis potteri (Brazos R., Brazos Co., Tx.); Notropis stramineus (Turkey Cr., Blanco Co., Tx.); Pimephales promelas (Brazos R., Burleson Co., Tx.); Ericymba buccata, Hybognathus nuchalis and Nocomis leptocephalus (Pushepatapa Cr., Washington Par., La.); Hybopsis amblops (Tangipahoa R., Tangipahoa Par., La.); and Notropis camurus (Thompson Cr., W. Feliciana Par., La.). Specimens were returned live to College Station, karyotyped, and deposited in reference collections at Texas A\&M University.

Chromosomes were prepared following the method of Gold (1974) which employs kidney tissue as the chromosome source. Chromosome number counts were made from negatives, and those showing the best spread metaphases were printed, cut out, and arranged into karyograms. Relative chromosome arm lengths were measured using precision callipers and classification of chromosomes by centromere position followed Levan et al. (1964).

\section{Results}

The species examined in this study are listed in Table 1. Counts of $2 n=50$ were found in over half of all cells counted per species (range $=59-81 \%$ ). Between 10 and 30 cells were counted per individual, and all individuals displayed sharp modes of 50 chromosomes. Hypomodal counts $(<50)$ were usually short by one or a few chromosomes and probably stemmed from loss during preparation, overlap, or miscounting. Hypermodal counts $(>50)$ represented less than $2 \%$ of all counts, and presumably stemmed from premature chromatid separation or miscounting. Individuals of both sexes were examined in 8 species (Table 1), but no sex chromosomes were identified. The diploid chromosome numbers of $P$. promelas and S. atromaculatus were reported previously as 50 and 52, respectively (Gravell and Malsberger 1965, Legendre and Steven 1969).

Table 1. Chromosome number counts from 13 species of North American Cyprinidae

\begin{tabular}{|c|c|c|c|}
\hline Taxon & $\begin{array}{l}\text { Number } \\
\text { of cells } \\
\text { examined }\end{array}$ & $\begin{array}{l}\% \\
\text { Modal } \\
\text { counts }\end{array}$ & $\begin{array}{c}\text { Modal } 2 n \\
\text { number }\end{array}$ \\
\hline Dionda episcopa $(3)^{t}$ & 74 & 59 & 50 \\
\hline Ericymba buccata (3) & 62 & 71 & 50 \\
\hline Hybognathus nuchalis $(4)^{\dagger}$ & 61 & 72 & 50 \\
\hline Hybopsis amblops (2) & 33 & 76 & 50 \\
\hline Nocomis leptocephalus (1) & 17 & 71 & 50 \\
\hline Notropis amabilis $(2)^{\dagger}$ & 38 & 79 & 50 \\
\hline Notropis atherinoides (3) & 60 & 65 & 50 \\
\hline Notropis atrocaudalis (3) & 67 & 66 & 50 \\
\hline Notropis camurus (5) & 66 & 67 & 50 \\
\hline Notropis potteri (2) & 49 & 63 & 50 \\
\hline Notropis stramineus (3) & 57 & 81 & 50 \\
\hline Pimephales promelas (2) & 42 & 62 & 50 \\
\hline Semotilus atromaculatus $(2)^{\dagger}$ & 36 & 64 & 50 \\
\hline
\end{tabular}

Parentheses refer to number of individuals examined.

† Individuals of only one sex examined. 
Modal karyograms for 10 of the species are shown in Figs. 1-10. Metaphases from D. episcopa, E. buccata, and $H$. nuchalis were of poor quality and studied no further. Each karyogram displays a graded series of small (ca. 4-9 $\mu$ ) chromosomes with centromere positions ranging from median to nearly terminal. This asymmetric pattern (Stebbins 1958, White 1973) is typical of most North American cyprinid karyotypes, and thus far has precluded attempts to pair homologues satisfactorily or classify chromosomes by centromere position within size groupings.

Our estimates of centromere positions and (haploid) chromosome arm numbers appear in Table 2. Differences among the species in the number of metacentric (M) and submetacentric (SM) pairs are shown, but between 1-5 pairs per species fell

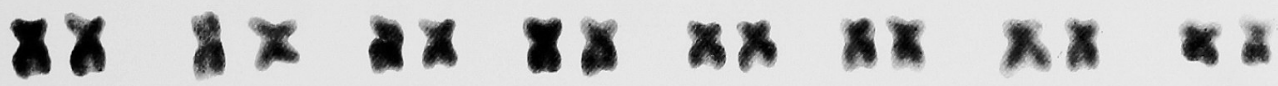

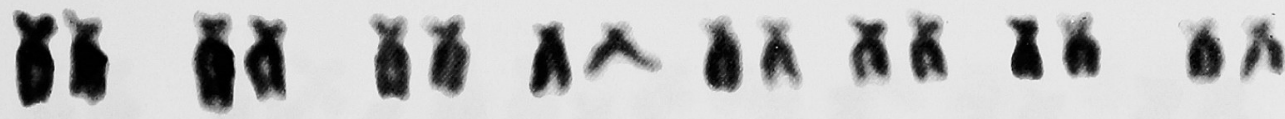

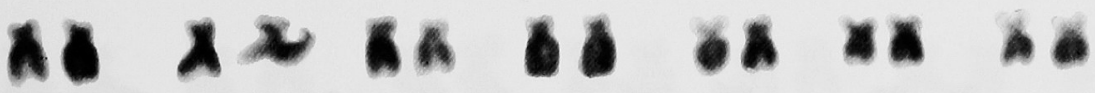 An In Hybopsis amblops 1

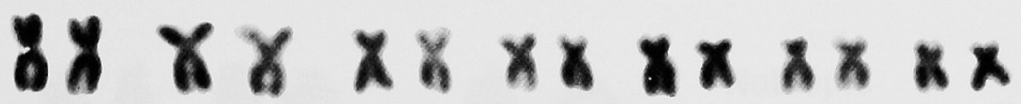

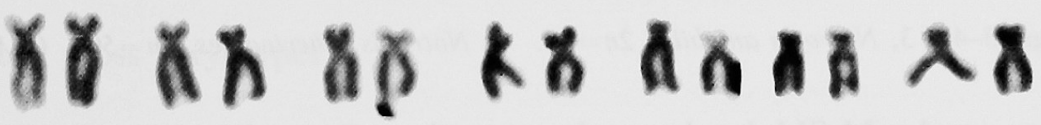

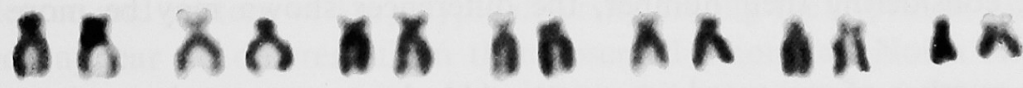 10 in $A \cap$ on $\begin{aligned} & \text { Nocomis } \\ & \text { leptocephalus } 2\end{aligned}$}

Figs. 1-2. 1, Hybopsis amblops, $2 n=50 . \quad 2$, Nocomis leptocephalus, $2 n=50 . \quad(\times 1100)$ 


\section{8 $8 \times 18 \times$

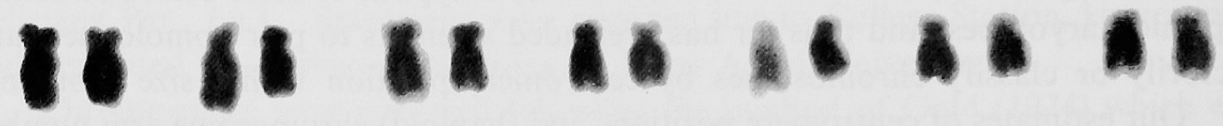

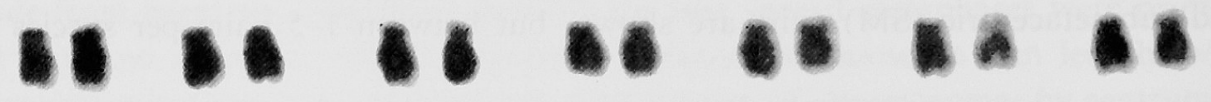 \\ A. A A A A BA Notropis 3

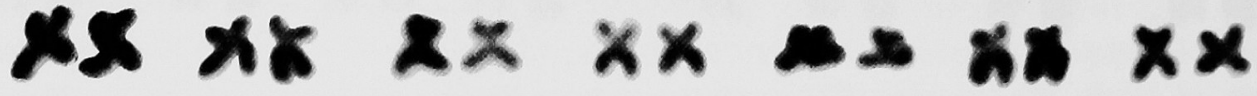

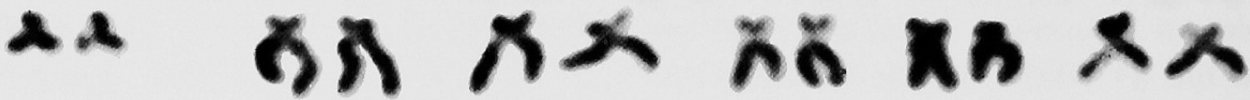 \\ A- -

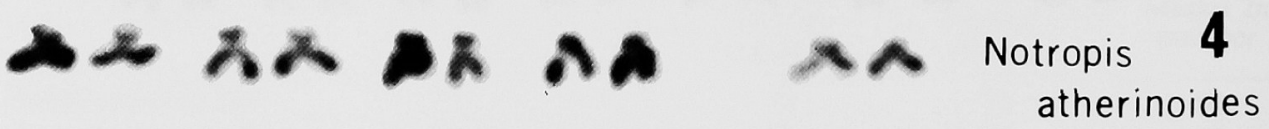

Figs. 3-4. 3, Notropis amabilis, $2 n=50 . \quad 4$, Notropis atherinoides, $2 n=50 . \quad(\times 1100)$

too close to the M-SM border to be unequivocally assigned to either category. These 'questionable M-SM' chromosomes were included in the SM category in Table 2; considering their number, the differences shown may be more apparent than real.

The number of measured acrocentric (A) chromosome pairs varied among the species from 0-4; eight of the ten species possessed only one or two A pairs. Haploid arm numbers varied as a function of the number of A (uni-armed) chromosomes, and hence ranged from 46-50. For reasons discussed at length elsewhere (Gold et al. 1978, 1979a), we interpret the variation in arm number conservatively; species with only small differences in arm number may have extremely similar, if 
1981

Cyprinid Karyotypes

109

$\Delta x$ an $x \times$ and ax $x$

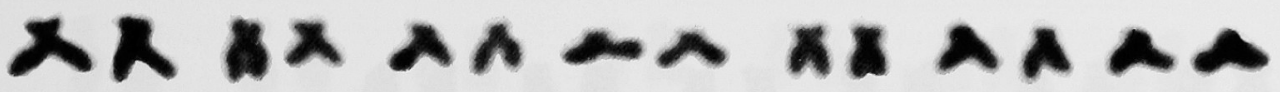

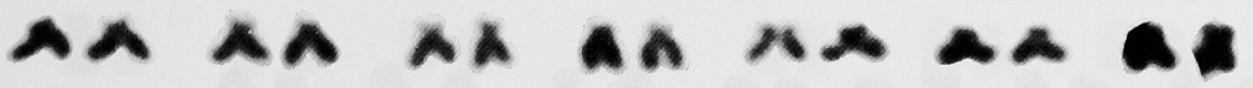

As AA AA

AA 一

Notropis

5 atrocaudalis

$x \times x \times 8 x \times x=2 x$

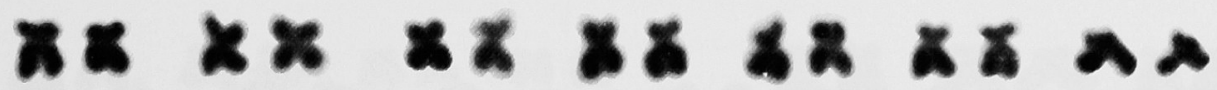

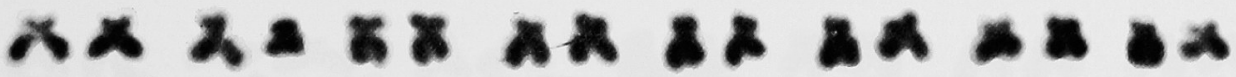

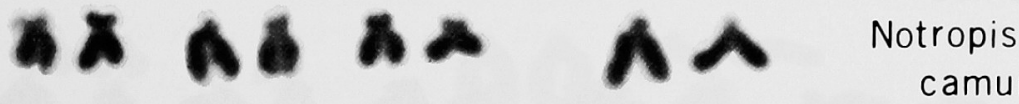

6

Figs. 5-6. 5, Notropis atrocaudalis, $2 n=50 . \quad 6$, Notropis camurus, $2 n=50 . \quad(\times 1100$ not identical, gross karyotypes.

Discussion

The degree and pattern of karyotypic diversity among the cyprinids examined in this study appear no different from that observed among all North American minnows examined to date (Fig. 11). Over $90 \%$ of the species assayed have $n=25$ chromosomes, and all fall in the range $n=24-26$; haploid arm numbers vary from $n=40-50$, but most species $(94 \%)$ fall in the range $46-50$. In any species, the number of chromosomes with median and submedian centromeres are very nearly the same, and uni-armed chromosomes (centromeres subterminal to terminal) normally comprise only a small fraction of the karyotype (Avise and Gold 1977, Gold et al. 1978, 


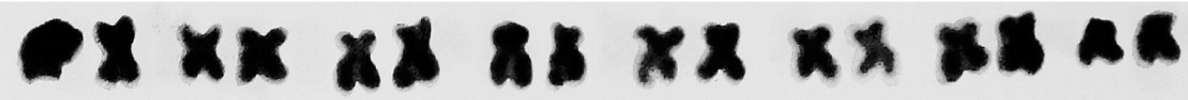 AS AG NG BA MS AD

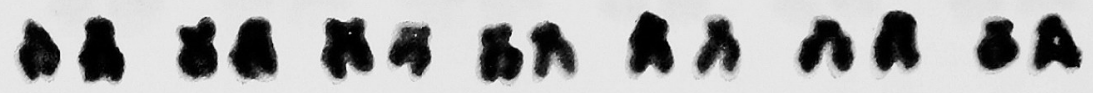

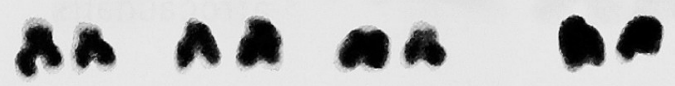 Notropis potteri $\mathbf{7}$ ax $8 \times \quad x \times \times 3 \times 3 \times x$

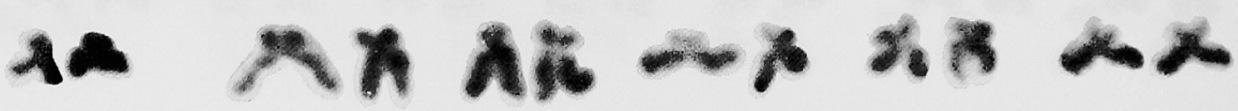

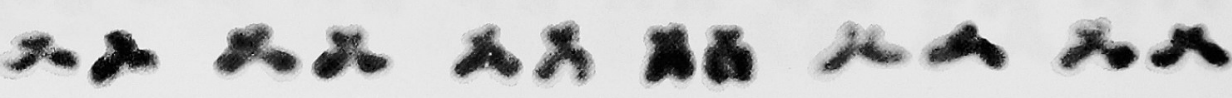

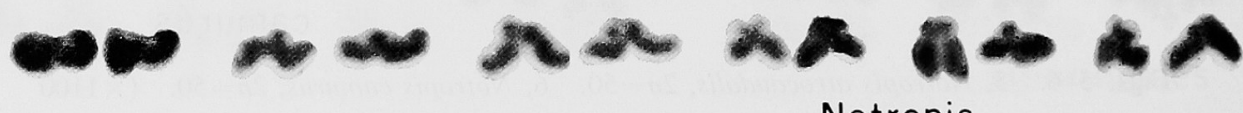 \\ Notropis \\ stramineus 8}

Figs. 7-8. 7, Notropis potteri, $2 n=50 . \quad 8$, Notropis stramineus, $2 n=50 . \quad(\times 1100)$

1979a).

The overall pattern of chromosomal evolution in these fishes is one of conservatism. That so few changes in chromosome number have occurred in a group as diverse as the North American minnows is striking, and clearly indicates that structural rearrangements affecting chromosome number (fusions, fissions, etc.) have not participated significantly in cyprinid evolution.

We interpret the variation in arm number cautiously. With present methods of fish chromosome preparation (Gold 1979) it is not possible to compare chromo- 
1888188828 as on

BS 81 BI AB HA BA 61

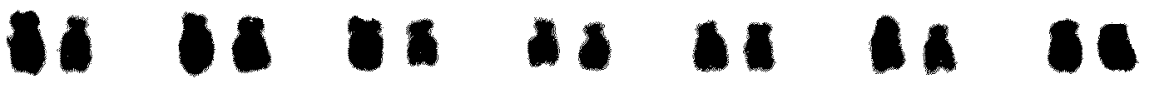

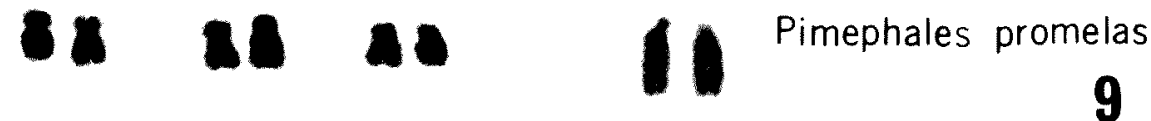

\section{$x x \times k x x x x x \propto x x x x$}

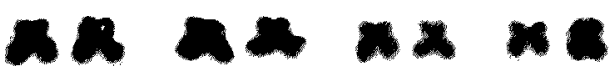

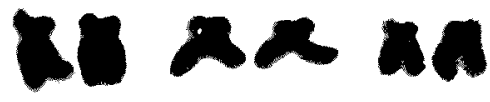

\section{na
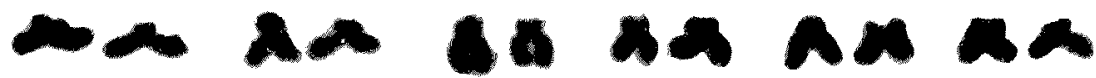

Semotilus
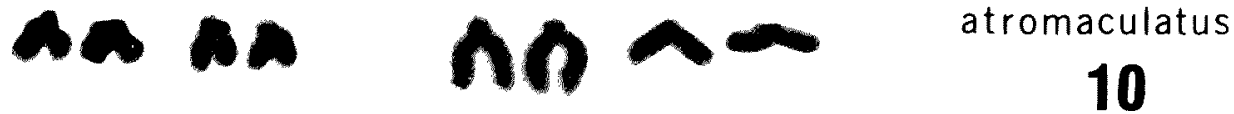

Figs. 9-10. 9, Pimephales promelas, $2 n=50 . \quad 10$, Semotilus atromaculatus, $2 n=50 . \quad(\times 1100)$

somes across species, nor is it possible to determine objectively homologous pairs within species. Further, centromere positions of several cyprinid chromosomes frequently fall too close to the submedian-subterminal border to be classified unambiguously as uni-armed or bi-armed. Nonetheless, the range of arm numbers observed along with the general asymmetry of cyprinid karyotypes, indicate that rearrangements affecting centromere position have occurred in the separate histories of many species. Chromosome structural changes which could affect centromere position include uneven pericentric inversions, non-reciprocal translocations, and increases (or decreases) in chromosomal DNA. We do not know how repeatable from laboratory to laboratory these observations of cyprinid arm number are, but at least some of the reported differences are undoubtedly real. On the 
Table 2. Estimated centromere positions of chromosome pairs and arm numbers of ten species of North American Cyprinidae

\begin{tabular}{lcc}
\multicolumn{1}{c}{ Taxon } & $\begin{array}{c}\text { Chromosome } \\
\text { formula } \\
\text { (haploid) }\end{array}$ & $\begin{array}{c}\text { Estimated } \\
\text { arm number } \\
\text { (haploid) }\end{array}$ \\
\hline Hybopsis amblops & $8: 15: 2$ & 48 \\
Nocomis leptocephalus & $7: 14: 4$ & 46 \\
Notropis amabilis & $7: 17: 1$ & 49 \\
Notropis atherinoides & $8: 16: 1$ & 49 \\
Notropis atrocaudalis & $5: 18: 2$ & 48 \\
Notropis camurus & $9: 14: 2$ & 48 \\
Notropis potteri & $8: 16: 1$ & 49 \\
Notropis stramineus & $8: 17: 0$ & 50 \\
Pimephales promelas & $7: 17: 1$ & 49 \\
Semotilus atromaculatus & $11: 12: 2$ & 48 \\
\hline
\end{tabular}

${ }^{\dagger}$ M-SM-A (metacentric-submetacentric-acrocentric).

${ }^{\text {tt }} \mathbf{M}$ and $\mathrm{SM}$ chromosomes = bi-armed; $\mathbf{A}$ chromosomes = uni-armed.

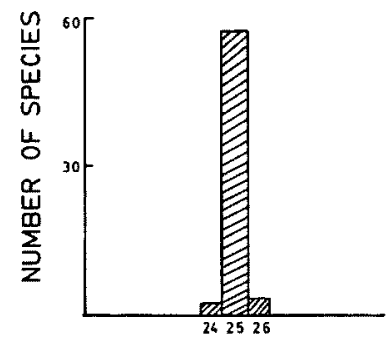

CHROMOSOME

NUMBER

(n)

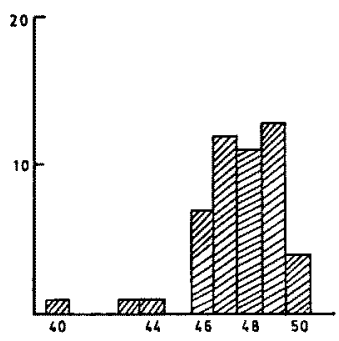

ARM

NUMBER

(n)

Fig. 11. Frequency distributions of chromosome numbers and arm numbers of assayed species of North American Cyprinidae. Data are from Gold et al. (1979b). Semotilus atromaculatus was considered both $n=25$ and $n=26$ (Legendre and Steven 1969; this paper).

whole, however, the pattern of arm number evolution in North American Cyprinidae also appears conservative. Most species have karyotypes containing large numbers of bi-armed chromosomes, and haploid arm numbers which vary from only 46-50. Several species appear to have identical gross karyotypes, and considering just species with $n=25$ chromosomes, 47 of $49(>95 \%)$ have arm numbers in the range $n=46-50$.

The above suggests that North American cyprinids are far more similar karyotypically, on the average, than might be expected if major chromosomal rearrangements had repeatedly contributed to reproductive isolation and speciation among the more than 200 extant species. Sampling additional species may prove otherwise, but the present data include about $25 \%$ of all living species and roughly $75 \%$ of all living genera. In short, the present data do not indicate a direct relationship between chromosomal evolution and speciation in these fishes. Gold et al. (1978) reached a similar conclusion from comparisons of rates of chromosome number evolution and speciation within living cyprinid genera with evolutionary rates of 
other vertebrate genera.

An additional feature of chromosome restructuring in organisms is that taxa which have experienced rapid and extensive organismal evolution tend also to have experienced rapid and extensive chromosomal change (Wilson 1976, Wilson et al. 1975, Bush et al. 1977). In Table 3, the North American cyprinids which have $n=$ 25 chromosomes and arm numbers in the range $n=47-49$ are listed. Several species have identical gross karyotypes, despite differences at the generic, tribal and subfamilial levels. At least qualitatively, the degree of organismal evolution among cyprinids appears far greater than the degree of chromosomal evolution (see also Gold et al. 1978).

Table 3. North American cyprinids with identical gross katryotypes

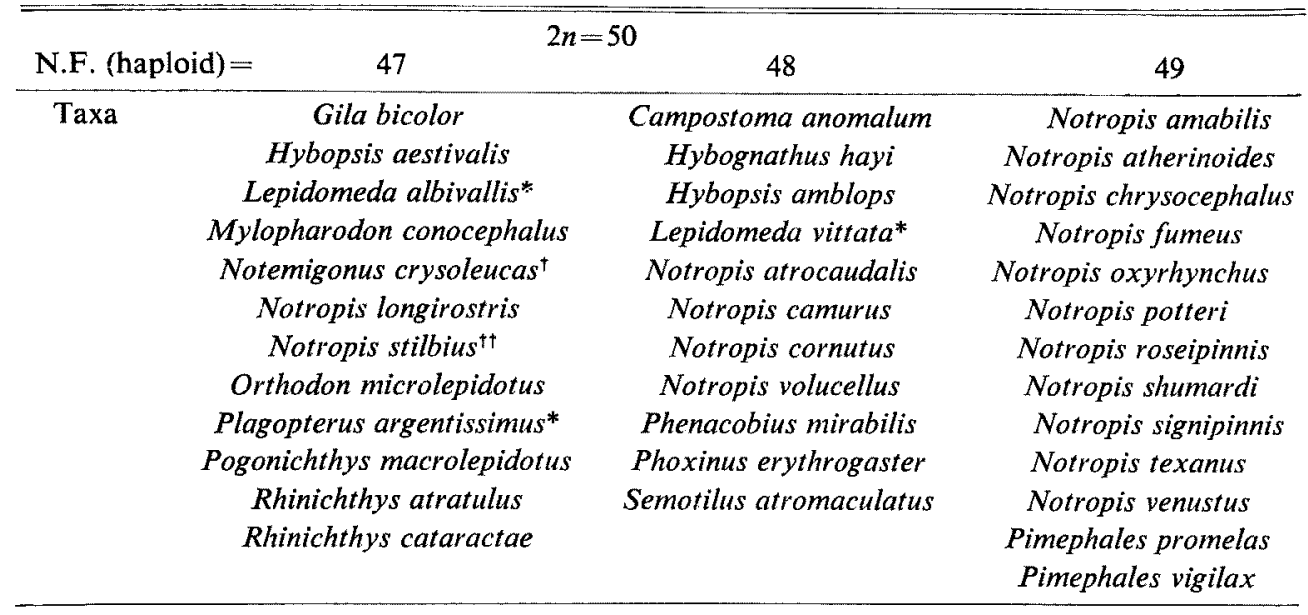

* Tribe Plagopterini; ${ }^{\dagger}$ subfamily Abramidinae; remainder are subfamily Leuciscinae, tribe Leuciscini. $1 t$ Arm number estimated by Campos and Hubbs (1973) from Denton and Howell (1969); remainder of data are from Gold et al. (1979b).

This study complements our previous conclusions (Avise and Gold 1977, Gold and Avise 1977, Gold et al. 1978, 1979a): the extensive and rapid radiation exhibited by North American Cyprinidae has not been accompanied by extensive and rapid gross chromosomal change. The molecular events which underlie speciation and progressive evolution in these fishes are unknown, but at present they do not appear to consist of structural gene changes (Avise 1977a, b, Avise and Ayala 1976) or changes in gross chromosome structure.

\section{Summary}

We have examined karyotypes of 13 species from eight genera of cyprinid fishes endemic to North America. All thirteen have diploid complements of 50 chromosomes. Arm numbers were estimated for ten species and varied from 46-50 (haploid). The pattern and extent of karyotypic diversity among these 13 species is typical of all North American cyprinids assayed to date. Almost all species have $n=25$ chromosomes, and variation in arm number is minimal. The conservatism in 
gross karyotype among these fishes is not commensurate with their apparently rapid and extensive radiation, and suggests that major chromosomal change has played only a minor role in cyprinid evolution.

\section{Acknowledgements}

Work was supported by funds administered through the Dean's Office of the College of Agriculture and the Texas Agricultural Experiment Station of Texas A\&M University. We thank Dr. W. Tomschoff for the use of a microscope, and Dr. H. J. Price for reviewing the manuscript.

\section{References}

Avise, J. C. 1977a. Is evolution gradual or rectangular? Evidence from living fishes. Proc. Natl. Acad. Sci. (U.S.A.) 74: 5083-5087.

- 1977b. Genic heterozygosity and rate of speciation. Paleobiology 3: 422-432.

— and Ayala, F. J. 1976. Genetic differentiation in speciose versus depauperate phylads: evidence from the California minnows. Evolution 30:46-58.

- and Gold, J. R. 1977. Chromosomal divergence and rates of speciation in two families of North American fishes. Evolution 31: 1-13.

Bush, G. L., Case, S. M., Wilson, A. C. and Patton, J. L. 1977. Rapid speciation and chromosomal evolution in mammals. Proc. Natl. Acad. Sci. (U.S.A.) 74: 3942-3946.

Campos, H. H. and Hubbs, C. 1973. Taxonomic implications of the karyotype of Opsopoeodus emiliae. Copeia (1973): 161-163.

Denton, T. E. and Howell, W. M. 1969. A technique for obtaining chromosomes from the scale epithelium of teleost fishes. Copeia (1969): 392-393.

Gold, J. R. 1974. A fast and easy method for chromosome karyotyping in adult teleosts. Prog. Fish-Cult. 36: 169-171.

- 1979. Cytogenetics. In "Fish Physiology" (W. S. Hoar, D. J. Randall and J. R. Brett, eds.). Volume VIII : 353-405. Academic Press, New York and London.

- and Avise, J. C. 1977. Cytogenetic studies in North American minnows (Cyprinidae) I. Karyology of nine California genera. Copeia (1977): 541-549.

-. Womac, W. D., Deal, F. H. and Barlow, J. A., Jr., 1978. Gross karyotypic change and evolution in North American cyprinid fishes. Genet. Res. 32: 37-46.

-, Whitlock, C. W., Karel, W. J. and Barlow, J. A., Jr. 1979a. Cytogenetic studies in North American minnows (Cyprinidae) VI. Karyotypes of thirteen species in the genus Notropis. Cytologia 44: 457-466.

-, Karel, W. J. and Strand, M. R. 1979b. Chromosome formulae of North American fishes. Texas Agricultural Experiment Station Publication No. MP-1411, pp. 1-24.

Grant, V. 1973. Plant Speciation. Columbia Univ. Press, New York.

Gravell, M. and Malsberger, R. G. 1965. A permanent cell line from the fathead minnow (Pimephales promelas). Ann. N. Y. Acad. Sci. 126: 555-565.

Kimmel, P. G. 1975. Fishes of the Miocene-Pliocene Deer Butte formation, southeast Oregon. Univ. Mich. Mus. Paleont. Pap. Paleont. 14: 69-87.

Legendre, P. and Steven, D. M. 1969. Denombrement des chromosomes chez quelques cyprins. Naturaliste Canada 96: 913-918.

Levan, A., Fredga, K. and Sandberg, A. A. 1964. Nomenclature for centromeric position on chromosomes. Hereditas 52: 201-220.

Levin, D. L. and Wilson, A. C. 1976. Rates of evolution in seed plants: Net increase in diversity of chromosome numbers and species numbers through time. Proc. Natl. Acad. Sci. (U.S.A.) 73: 2086-2090. 
Miller, R. R. 1959. Origin and affinities of the freshwater fish fauna of Western North America. Zoogeography. Amer. Assoc. Advan. Sci. Pub. 51: 187-222.

- 1965. Quaternary freshwater fishes of North America. $1 n$ "The Quaternary of the United States" (H. E. Wright, Jr. and D. G. Frey, eds.), pp. 569-581. Princeton Univ. Press, Princeton, New Jersey.

Prager, E. M. and Wilson, A. C. 1975. Slow evolutionary loss of the potential for interspecific hybridization in birds: a manifestation of slow regulatory evolution. Proc. Natl. Acad. Sci. (U.S.A.) 72: 200-204.

-, Fowler, D. P. and Wilson, A. C. 1976. Rates of evolution in conifers (Pinaceae). Evolution 30: 637-649.

Smith, G. R. 1975. Fishes of the Pliocene Glenns Ferry formation, southeast Idaho. Univ. Mich. Mus. Paleont. Pap. Paleont. 14:1-68.

Stebbins, G. L. 1958. Longevity, habitat, and release of genetic variability in the higher plants. Cold Spring Harbor Symp. Quant. Biol. 23: 365-378.

White, M. J. D. 1973. Animal Cytology and Evolution. Third Edition. Cambridge Univ. Press.

- 1977. Modes of Speciation. W. H. Freeman and Co., San Francisco.

- 1978. Chain processes in chromosomal speciation. Syst. Zool. 27: 285-298.

Wilson, A. C. 1975. Evolutionary importance of gene regulation. Stadler Genet. Symp. 7:117134.

- 1976. Gene regulation in evolution. In "Molecular Evolution" (F. J. Ayala, ed.), pp. 225-234. Sinauer Assoc., Inc., Sunderland, Mass.

-, Bush, G. L., Case, S. M. and King, M. C. 1975. Social structuring of mammalian populations and rate of chromosomal evolution. Proc. Natl. Acad. Sci. (U.S.A.) 72: 5061-5065. 